UDC $614 ; 311.12 ; 351 / 354$

DOI: 10.21668/health.risk/2018.3.01.eng

\title{
ON IMPLEMENTATION OF POPULATION LIFE QULITY ASSESSMENT INTO SOCIAL-HYGIENIC MONITORING SYSTEM
}

\author{
A.Yu. Popova ${ }^{1}$, N.V. Zaitseva ${ }^{2}$, I.V. May $^{2}$ \\ ${ }^{1}$ Federal Service for Surveillance on Consumer Rights Protection and Human Wellbeing, Build 5, 7, 18 Vadkovskiy \\ lane, Moscow, 127994, Russian Federation \\ ${ }^{2}$ Federal Scientific Center for Medical and Preventive Health Risk Management Technologies, 82 Monastyrskaya Str., \\ Perm, 614045, Russian Federation
}

The article dwells on grounds for implementing population life quality assessment into social-hygienic monitoring system; it also outlines some methodical approaches to such assessment. Certain techniques are now applied both in Russia and worldwide but the authors propose to update them by application of approaches oriented at life quality assessment as a combination of life quality potential (in a country, region, or a municipal district) and risks of a decrease in this potential. The suggested approaches allow both to calculate integral indexes and to fragment life quality potential and risks in order to solve managerial tasks. It is shown that socialhygienic monitoring system is able to provide informational, methodical, and analytical base for life quality assessment due to it being a state system that has long been accumulating medical-demographic, social-economic, sanitary-hygienic, and other data on Russian regions functioning.

Implementation of life quality assessment into social-hygienic monitoring system will require to improve and enhance interdepartmental interaction; to make each concerned party have greater interest in obtaining relevant and correct indexes of population life quality and separate components of its potential and risks; to include a substantial sociological component into systems of observations as it will help to assess people's satisfaction with their living standard in general and with its specific components; to develop and implement methodical support, as well as hardware and software for assessment of life quality including its separate components and to enlarge the information fund of social-hygienic monitoring; to develop skills of experts employed at Rospotrabnadzor's bodies and organizations who are responsible for formation of regional and federal information funds and for analytical data processing.

Key words: social-hygienic monitoring, life quality, living standard, potential, integral index, risk.

The tasks on improving life quality of Russians are considered as priorities in the Russian Federation strategy for national security ${ }^{1}$. At the same time, "life quality" is considered as an integral index of population satisfaction with the material, social and spiritual aspects of life $[1,2]$. The strategy for national security assumes improvement of citizens life quality by ensuring food safety, scaling-up availability of comfortable housing, diversity and safety of goods and services, achieving a high level of education and healthcare, fare

C Popova A.Yu., Zaitseva N.V., May I.V., 2018

Anna Yu. Popova - Doctor of Medicine, Professor, Head (e-mail: depart@gsen.ru; tel.: +7 (499) 458-95-63).

Nina V. Zaitseva - Academician of the Russian Academy of Sciences, Doctor of Medical Sciences, Professor, Scientific Director (e-mail: znv@ fcrisk.ru; tel.: +7 (342) 237-25-34).

Irina V. May - Doctor of Biological Sciences, Professor, Deputy Director for Scientific Work (e-mail: may@fcrisk.ru; tel.: +7 (342) 236-32-64).

${ }^{1}$ On the Russian Federation's National Security Strategy: Presidential Decree No. 683 ddt. 31.12.2015. ConsultantPlus. Available at: http://www.consultant.ru/document/cons_doc_LAW_191669/743474b198a4e9a6e9e181 d9451 aafc27185f735/ (access date: 22.06.2018) (in Russian). 
wages and salaries, creating favorable living conditions, a wide network of accessible social, engineering and transport infrastructures for limited mobility people, etc.

In global practice, "life quality" is being considered in different ways. This term appeared in scientific literature in 1996, with reference of organs transplantation in the perception of patients. Inevitably, measures of "life quality" for a long time have been complied only with the purpose of analyzing medical care effectiveness $[3,4]$. This practice still goes on at present, allowing doctors and researchers to evaluate effectiveness and efficiency of therapy according to a system of personal indices $[5,6]$. At the same time, many authors recognize the need to take into account a significantly wider range of parameters characterizing population life quality [7-9].

In 2011, experts of Organization for Economic Cooperation and Development (OECD), having summarized multidirectional studies on life quality from economic, sociological, environmental and other points, suggested using the so-called "Better Life Index" [10]. The better life index includes 11 aspects: 1) income and material security; 2) employment and earnings; 3) housing; 4) state of health; 5) work and rest balance; 6) education and skills; 7) socialization; 8) involvement in public life and quality of government control; 9) environmental quality; 10) personal security; 11) perceptions of satisfaction with life. The first three aspects define material well-being, points 4-11: life quality of an individual. All aspects are described by one or two parameters, each, in turn, being represented by one or two indexes. All indexes become normal so that the best score for all countries is " 1 ", and the worst is " 0 ". After that, these indexes come to evaluation of the characteristics as the arithmetic average of their normalized values. Similarly, the levels of characteristics are aggregated to obtain a final score in each aspect. Russian Federation is also evaluated in terms of Better life index among other countries [11].

Not all national researchers consider such approach as adequate to the real situation in the Russian society [8]. However, despite the fact that the index chosen by OECD can be discussed, criticized, viewed as insufficiently correct for Russian Federation, it is necessary to take into account the global focus on these indexes, to evaluate parameters that lower Russia's rating, and strive to improve them.

In this regard, it seems relevant to systematically calculate and monitor the life quality index for the country as a whole, its certain regions and municipalities, as well as decomposition of this index into indices actually managed by the state and specifically by certain authorized executive bodies.

In recent years, various approaches to assessing life quality have been proposed, mainly for the rating tasks of Russian regions and cities [7, 12, 13]. The latter is due to the fact that the country as a whole and almost all its territories are interested in the influx of able-bodied population. In a complicated demographic situation in the country, many regions and cities declare an orientation towards the formation of a "health-saving" environment, considering the population high life quality as an important factor of competitiveness and attractiveness of any territory [14]. This trend is global, since population satisfaction with a living standard ensures social stability of a society, and is one of the conditions for the country's sustainable development [15].

In this regard, it appears that any assessments of the population life quality should not only be considered (and not so much) as means of comparing territories, but should be the tools for substantiating control actions, identifying the most acute problems requiring solutions and forming the most efficient and effective measures. Such approach is welcomed by many researchers. At the same time, life quality indexes are considered by some authors as criteria in evaluating government activities [16-18]

The Federal Service for Surveillance over Consumer Rights Protection and Human Well-Being ensures control over compliance with the mandatory requirements for a significant number of indexes that are components of life quality: parameters of habitat, infectious and non-infectious morbidity, working condi- 
tions, educational process, etc. The Service monitors these indexes level in all regions of the country and performs an analysis of the effectiveness and efficiency of actions to control these indexes.

Socio-hygienic monitoring (SGM), implemented by Rospotrebnadzor, is a unique interdepartmental state system for collecting and analyzing various medical-demographic, epidemiological, ecological-hygienic and socio-economic data [19]. Currently, SGM Federal Information Fund has accumulated over 65 million units of information on the medical and demographic indexes of the regions over a long-term period, habitat parameters, socioeconomic characteristics, etc. Versatility of the collected data, focus on ensuring health and sanitary-epidemiological well-being of the population, the state and interdepartmental nature of the system give SGM an opportunity to act as the basis for an integral assessment of the population life quality. At the same time, this system can be the basis for substantiating decisions on managing certain components of life quality, taking into account the functions and powers of Rospotrebnadzor or other authorities, business and civil society.

In general, the implementation of methods for assessing life quality in SHM will result in a significant expansion of the system analytical capabilities and an increased demand from the Government, civil society, other federal executive bodies, etc. At the same time, it seems reasonable to develop approaches that reflect situation in Russian Federation as closely as possible allowing for the global method of calculating life quality index. The latter will provide an opportunity to obtain the forecast estimates of the Russian Federation rank in global rating, and define measures to improve the country's status at the international level.

In this context, it is important that socio-hygienic monitoring system for many years solves problems of identifying the priority risk factors, including the ones that compromise life quality. Identification, quantification and structuring risk factors allows for better controllability in many social processes, forecasting trends in the indexes and taking preventive measures $[20,21]$.

In this regard, it seemed relevant to include risk assessment methods in the system of estimated indexes of the population life quality.

The purpose of implementing the population life quality assessment in the system of socio-hygienic monitoring is to provide public authorities, civil society, local governments, other stakeholders with the information and analytical data on the potential of population life quality and risks for deterioration of this quality as a basis for making management decisions at all levels.

The main principles of the system development as related to introducing life quality assessment methods into it are:

1) scientific validity of methodological approaches adapted to the realities in Russian Federation on effective management of the population life quality based on an assessment of the potential and risks for deterioration of life quality;

2) transparency and systematic assessments based on socio-hygienic monitoring data and the associated state and departmental statistics;

3) development of an analytical apparatus that enhances integrated assessment and evaluation of certain components of the potential and risks to life quality at the level of the country and its particular regions (municipalities);

4) transparency of the results for all stakeholders.

Due to the fact that achieving an effective management of environmental quality parameters is eventual provided only a clear targeting to the actions-focus object, the methodological basis for assessing life quality level can be the calculations of life quality potential indexes (in a country, region, city) parallel to the assessment of risks to the citizens life quality.

The general algorithm for assessing life quality level for management tasks and minimizing risks within the framework of social and hygienic monitoring system suggests: 
- estimating life quality integral index potential in a territory (allowing for its decomposition to the level required to manage it);

- estimating risks for decline in life quality integral index (allowing for its decomposition to the level required to manage it);

- estimating general life quality level as a value that reflects both the potential and the risks associated with the population life quality;

- trends' analysis and comparative analysis of life quality index at the country, regional, municipal levels.

Monitoring the integral indexes and their certain components, and comparing the indexes periodically will allow for evaluation of the changes dynamics in the potential or risks in a territory, the effectiveness and efficiency of control actions.

The life quality potential reflects a system of indexes, the high level of which (the maximum approximation to the most favorable one, achieved in the country, or a target level, the presence of a pronounced tendency to improvement, etc.) enhances the population life quality. Potential is determined through the integral index, approximated to the "better life index", by the calculation method. For comparison of various characteristics measured in scales of different range and dimension, a relative non-dimensional indicator is determined, reflecting the approximation degree of an absolute index of a characteristic to the best (or target) index (1):

$$
f_{t}^{\grave{e ̀ ~ o ̀ ~}}=\frac{1}{N} \sum_{i=1}^{N} \frac{f_{i t}}{f_{i t}^{\max }}
$$

where $f_{t}^{\text {è } i o ̀ ~}$ is the integral index of the population life quality at the $t$-th territory; $f_{i t}^{\max }$ is the maximum value of the $i$-th index for $f_{i t}$ among all the territories; $N$ is the number of factors of a potential being taken into account

The value $f_{t}^{\grave{e} i o ̀}$ is considered as a potential for life quality.

The potential for life quality can be assessed as:

$$
\text { high, at } f_{t}^{\grave{e} i o ̀} \geq 0,8 \text {, }
$$

$$
\begin{aligned}
& \text { average, at } 0,6 \leq f_{t}^{\text {èi }}<0,8, \\
& \text { low, at } 0,4 \leq . f_{t}^{\text {è }}<0,6, \\
& \text { extremely low, at } f_{t}^{\text {è } \dot{o}}<0,4 .
\end{aligned}
$$

Each object under assessment (country as a whole, its separate region, city, any other municipality) is characterized by each individual indicator (fit) and the integral index as a whole.

The ratio $f_{\text {it }} / f_{\text {it }}^{\max }$ characterizes the progress degree of the best (target) index in a territory; the ratio $\left(f_{\text {it }} / f_{\text {it }}^{\text {max }}\right) / f_{\mathrm{t}}^{\text {int }}$ is the contribution of a specific group of indexes to the overall life quality index.

The list of indices that truly reflect the population life quality potential should include:

1) material well-being level of a household and/or an individual;

2) population employment and occupational safety;

3) availability of high-quality housing;

4) medical and demographic indices of a society;

5) work and rest balance;

6) level of education and leisure activities;

7) social binds;

8) involvement in public life and quality of government control;

9) environmental quality;

10) personal security;

11) perceptions of satisfaction with life.

If there are data on significance of certain life quality components for the population, the weighting factors can be established for each group of indices.

To obtain correct comparative assessments, all objects (countries, regions, municipalities) should be characterized by a single set of indices.

Calculation of life quality potential should include not only the static indices characterizing the current (or averaged over a given period) state of an object, but also the indices characterizing index dynamics (increase, decrease, rate of change, etc.)

Index decomposition allows you to identify priority problems and determine vectors of actions to improve population life quality. Within the framework of socio-hygienic monitoring, a comparative and (or) dynamic 
analysis of life quality components can be performed, which includes interests of certain state (municipal) bodies authorized in a particular field of activity.

Risks that do not allow realize the potential of a territory in terms of population life quality are determined by the parameters characterizing the negative phenomena of social life as regard to violations of individual health, safety, living conditions, quality of environmental objects, etc.

Using the classical definition of risk, as the product of negative events probability and their consequences, the basic formula (2) for assessing risk of decrease in life quality is proposed:

$$
R=\frac{1}{N} \sum_{i=1}^{N} p_{i} g_{i},
$$

where $p_{i}$ is the occurrence probability of a negative event or its frequency over a certain period of time (for example, a year); $g_{i}$ is the severity of these events consequences in terms of their impact on life quality; $N$ - the number of risk factors being considered.

The task to determine the severity of negative events consequences is exploratory in nature, and is aimed at formalizing causal relationships between the frequency of events and the population life quality of the regions, assessed by a special index or indexes system (3):

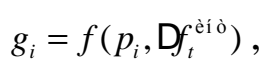

where $\Delta f_{t}^{\mathrm{eì} i}$ is the change in life quality index.

The resulting risk index for the rating scale is classified as

high at $R \geq 0,6$,

average at $0,3 \leq<0,6$,

low at $0,05 \leq<0,3$,

extremely low at $<0,05$.
The study of cause-effect relationships involves using systems analysis methods that allow determine main patterns for regional distribution of indexes that reflect life quality.

The source of information to assess probability of negative events that determine life quality is state statistical reporting, compiled by Federal State Statistics Service, the Ministry of Health of Russian Federation, Ministry of Internal Affairs, Ministry of Natural Resources and Ecology, Ministry of Education and other federal executive bodies whose data are accumulated in the hygienic monitoring.

The list of indexes that really reflect the risks to population life quality is formed for the same 11 groups, which determine the life quality potential. An example of the initial data that allows for assessment of the potentials and risks to life quality is given in Table 1 .

Since the formula for calculating risk of loss (decrease) in life quality implies a summation of risks formed by different factors, the assessment of individual indexes or indexes groups' shares to the overall risk level characterizes signification of factors and allows for management priorities.

Cross-spectrum analysis of the potential and risk indexes allows us to draw conclusions about the general life quality level of a country's population, focusing on the objects of management (Table 2). Regions (territories) with high potential and low risks, i.e. the leading regions (cities), whose indexes should be looked up to, and whose experience should be adopted.

Regions (territories) with a high potential that can be formed by a high level of employment and wages of the population, growth of the domestic regional product and housing provision at the same time can be featured with high risks of medical and demographic losses due to climatic peculiarities of the subject, population aging, adverse environmental or sanitary epidemiological situation, etc. In these cases, an analysis of life quality assessment results should provide guidance for developing risk management activities. 
Table 1

Examples of indexes accumulated in SHM systems for assessing life quality potential and its decrease risks

\begin{tabular}{|c|c|c|c|}
\hline $\begin{array}{c}\text { Life quality } \\
\text { potential index }\end{array}$ & Data source & $\begin{array}{c}\text { Risk factor for life } \\
\text { quality }\end{array}$ & Data source \\
\hline $\begin{array}{l}\text { Life expectancy at } \\
\text { birth }\end{array}$ & $\begin{array}{l}\text { Federal State Statistics Service } \\
\text { (Rosstat). Predictions by cal- } \\
\text { culations method for "Life ex- } \\
\text { pectancy at birth (years)" index }\end{array}$ & Total mortality & $\begin{array}{c}\text { Rosstat. Form C51 "Distribution of } \\
\text { the deceased by sex, age groups and } \\
\text { causes of death in the specified } \\
\text { year". }\end{array}$ \\
\hline \multirow{2}{*}{$\begin{array}{l}\text { Share of economi- } \\
\text { cally active popu- } \\
\text { lation of a territory } \\
\text { in the total popula- } \\
\text { tion (country, re- } \\
\text { gion, etc.) }\end{array}$} & \multirow{2}{*}{$\begin{array}{l}\text { Rosstat Tables 1BCH-П } \\
\text { "Population size by sex and } \\
\text { age, as of January, 1st of the } \\
\text { specified year"; FIF SHM, } \\
\text { Section 1. "Medical- } \\
\text { demographic indexes }\end{array}$} & $\begin{array}{l}\text { Adult mortality ex- } \\
\text { cluding deaths of } \\
\text { retirement age people }\end{array}$ & $\begin{array}{l}\text { Rosstat Form 1-Y "Information on } \\
\text { the deceased", Rosstat Tables } \\
\text { 1BCH-П "Population size by sex } \\
\text { and age, as of January, 1st of the } \\
\text { specified year"; FIF SHM, Section } \\
\text { 1. "Medical-demographic indexes" }\end{array}$ \\
\hline & & $\begin{array}{c}\text { Share of people } \\
\text { working in contact } \\
\text { with harmful and } \\
\text { adverse factors of } \\
\text { occupational envi- } \\
\text { ronment and labor } \\
\text { process }\end{array}$ & $\begin{array}{l}\text { FIF SPM, Table } 8.2 \text { "Number of } \\
\text { people working in contact with } \\
\text { harmful and adverse factors of occu- } \\
\text { pational environment and labor pro- } \\
\text { cess by type of factors per economic } \\
\text { activity" }\end{array}$ \\
\hline $\begin{array}{l}\text { Share of popula- } \\
\text { tion provided with } \\
\text { drinking water }\end{array}$ & $\begin{array}{c}\text { Federal State Statistics Service. } \\
\Phi-18 \text { "Information on sanitary } \\
\text { condition of the subject of the } \\
\text { Russian Federation" }\end{array}$ & $\begin{array}{l}\text { Percentage of drink- } \\
\text { ing water samples } \\
\text { studied that do not } \\
\text { meet sanitary and } \\
\text { epidemiological re- } \\
\text { quirements }\end{array}$ & $\begin{array}{c}\text { Federal State Statistics Service. } \Phi \text { - } \\
18 \text { "Information on sanitary condi- } \\
\text { tion of the subject of the Russian } \\
\text { Federation" }\end{array}$ \\
\hline $\begin{array}{l}\text { Number of living } \\
\text { space per person } \\
(\mathrm{m} 2 / \text { person })\end{array}$ & $\begin{array}{c}\text { FIF SHM. Section } 3 \text { "Infor- } \\
\text { mation on social and economic } \\
\text { status of a territory" }\end{array}$ & $\begin{array}{l}\text { Share of dilapidated } \\
\text { and emergency hous- } \\
\text { ing }\end{array}$ & $\begin{array}{l}\text { Federal State Statistics Service. Cal- } \\
\text { culations method for "Share of di- } \\
\text { lapidated and emergency housing in } \\
\text { the total amount of housing stock of } \\
\text { a constituent entity of the Russian } \\
\text { Federation" index }\end{array}$ \\
\hline
\end{tabular}

\section{Table 2}

Matrix for determining population life quality level as a combination of potential and risks parameters

\begin{tabular}{|c|c|c|c|c|}
\hline $\begin{array}{c}\text { Potential } \\
\text { index }\end{array}$ & $\begin{array}{c}\text { Extremely } \\
\text { low }\end{array}$ & Low & Moderate & High \\
\hline High & $\begin{array}{c}\text { High } \\
\text { level }\end{array}$ & $\begin{array}{c}\text { High } \\
\text { level }\end{array}$ & $\begin{array}{c}\text { Moderate } \\
\text { level }\end{array}$ & Low level \\
\hline Moderate & $\begin{array}{c}\text { High } \\
\text { level }\end{array}$ & $\begin{array}{c}\text { Moderate } \\
\text { level }\end{array}$ & $\begin{array}{c}\text { Moderate } \\
\text { level }\end{array}$ & Low level \\
\hline Low & $\begin{array}{c}\text { Moderate } \\
\text { level }\end{array}$ & $\begin{array}{c}\text { Moderate } \\
\text { level }\end{array}$ & Low level & $\begin{array}{c}\text { Extremely } \\
\text { low level }\end{array}$ \\
\hline $\begin{array}{c}\text { Extremely } \\
\text { low }\end{array}$ & Low level & $\begin{array}{c}\text { Low } \\
\text { level }\end{array}$ & $\begin{array}{c}\text { Extremely } \\
\text { low level }\end{array}$ & $\begin{array}{c}\text { Extremely } \\
\text { low level }\end{array}$ \\
\hline
\end{tabular}

Regions (territories) with low potential and high life quality risks require principal programs of a complex development, etc.

Decomposition of both the indexes of potential and risk makes it possible to identify vectors of actions that, with the same integral indexes, can be completely different in different regions.

As of today, the data accumulated in the federal information fund system, state and industry statistics allow for an in-depth analysis of risks to life quality within the minimum period of time. The most significant problems for obtaining the objective assessments of life quality are the preparation and processing data from sociological studies on citizens' perceptions of 
life quality in the regions. However, the experience of such studies in the country is available, including the experience gained by scientific organizations of Rospotrebnadzor [22, 23]. Completing the social and hygienic monitoring system with sociological research data will expand the scope of application of the methodology for assessing and managing risks of a different nature, including risks to the population life quality [24].

In general, the implementation of life quality assessment in the system of social and hygienic monitoring will require:

- strengthening and intensifying the interdepartmental interaction, increasing the involvement of each of the parties in obtaining adequate and correct indexes of population life quality and certain components of its potential and risks;

- mainstreaming into the monitoring system of an essential sociological component, which makes it possible to assess the population satisfaction with the living standard in general and with its certain quality components;

- development and implementation of methodologies and hardware-software for as- sessing life quality and its certain components, and expansion of SHM federal information fund;

- professional development of Rospotrebnadzor bodies and organizations' experts, staffing the regional and federal information funds and performing analytical data processing.

The development of SHM system in terms of launching new functions is supposed to be implemented, having worked out the approaches to assessing the potential and risks to life quality on the example of several pilot regions (municipalities) with identification of effective mechanisms for applying results when making management decisions. The final step should be a systematic assessment of life quality of the country as a whole and of separate regions, informing the government, regional and municipal authorities and civil society on the results obtained.

Funding. Our research was not granted any sponsors' support.

A conflict of interests. The authors state there is no conflict of interests.

\section{References}

1. Zalevskiy G.V., Loguntsova O.I., Nepomnyashchaya V.A. Kachestvo zhizni kak kompleksnaya kharakteristika zhiznedeyatel'nosti cheloveka [Quality of life as a complex characteristic of life activity]. Sibirskii psikhologicheskii zhurnal, 2002, no. 16-17, pp. 102-103 (in Russian).

2. Malikov N.S. K voprosu o soderzhanii ponyatiya "kachestvo zhizni" i ego izmereniyu [On content of "life quality" concept and its measuring]. Uroven' zhizni naseleniya regionov Rossii, 2002, no. 2, pp. 17-23 (in Russian).

3. Libis R.A., Kots Ya.I., Ageev F.T., Mareev V.Yu. Kachestvo zhizni kak kriterii uspeshnoi terapii bol'nykh khronicheskoi serdechnoi nedostatochnost'yu [Life quality as a criterion of successful therapy for patients with chronic cardiac insufficiency]. Russkii meditsinskii zhurnal, 1999, vol. 7, no. 2, pp. 5559 (in Russian).

4. Ware J.E., Snow K.K., Kosinski M., Gandek B. Sf-36 Health Survey: Manual and Interpretation Guide. Boston: The Health Institute, New England Medical Center, 1993, 316 p. Available at: https://www.researchgate.net/profile/John Ware/pub-

lica-

tion/247503121_SF36_Health_Survey_Manual_and_Interpretation_Guide/links/56a0e80b08ae21a5642d 5ad3/SF36-Health-Survey-Manual-and-Interpretation-Guide.pdf (22.06.2018). 
5. Akinyemiju T.F., Zhao X., Sakhuja S., Jolly P. Life-course socio-economic status and adult BMI in Ghana; analysis of the WHO study on global ageing and adult health (SAGE). International Journal for Equity in Health, 2018, vol. 15, no. 1, pp. 1-8.

6. Provotorov V.M., Kotochigova T.V. Kachestvo zhizni bol'nykh khronicheskoi obstruktivnoi bolezn'yu legkikh s khronicheskoi serdechnoi nedostatochnost'yu [Quality of life of patients with chronic obstructive pulmonary disease with chronic heart failure]. Vrach-aspirant, 2011, vol. 48, no. 5.1, pp. 237-240 (in Russian).

7. Makhmudova M.M., Koroleva A.M. Kachestvo zhizni naseleniya: sushchnost', metodiki otsenki i sovremennoe sostoyanie v Ural'skom federal'nom okruge [The quality of life of the population: essence, assessment methods and state-of-the-art in the Ural Federal District]. Vestnik Chelyabinskogo gosudarstvennogo universiteta, 2014, vol. 353, no. 24, pp. 21-26 (in Russian).

8. Golovin A.A., Vlasova T.A., Koroleva N.M. Metodika otsenki kachestva zhizni naseleniya [Методика оценки качества жизни населения]. Vestnik Belgorodskogo universiteta kooperatsii, ekonomiki i prava, 2018, vol. 71, no. 4, pp. 115-122 (in Russian).

9. Pineo H., Glonti K., Rutter H., Zimmermann N., Wilkinson P., Davies M. Characteristics and use of urban health indicator tools by municipal built environment policy and decision-makers: a systematic review protocol. Systematic Reviews, 2017, vol. 6, pp. 2. DOI: 10.1186/s13643-017-0406-x

10. What's the Better Life Index? Better Life Index. Available at: http://www.oecdbetterlifeindex.org/about/better-life-initiative/ (01.08.2018).

11. Russian Federation. Better Life Index. Available at: http://www.oecdbetterlifeindex.org/countries/russian-federation/ (01.08.2018).

12. Volkov V.N. Reitingi gorodov Rossii po kachestvu zhizni naseleniya kak otrazhenie effektivnosti obrazovatel'nykh sistem [Life quality ratings of the Russian cities as a reflection of the educational system efficiency]. Nepreryvnoe obrazovanie: XXI vek, 2016, vol. 13, no. 1, pp. 50-60 (in Russian).

13. Fomina E.S., Ivanova T.A. Opredelenie reitinga sub"ektov rf po urovnyu kachestva zhizni $s$ pomoshch'yu postroeniya integral'nogo indikatora [The rank determination of the federal subjects of russia based on qol (quality of life) level by building an integral indicator]. Prilozhenie matematiki $v$ ekonomicheskikh i tekhnicheskikh issledovaniyakh, 2014, vol. 4, no. 1, pp. 192-197 (in Russian).

14. Kemalov A.M. Metodika otsenki kachestva zhizni naseleniya gorodov-millionnikov [Procedure of population life quality assessment in cities with over a million dwellers]. Alleya nauki, 2017, vol. 2, no. 10, pp. 184-190 (in Russian).

15. Wu S., Li D., Wang X., Li S. Examining component-based city health by implementing a fuzzy evaluation approach. Ecological Indicators, 2018, vol. 93, pp. 791-803.

16. Tkachev A.N., Lutsenko E.V. Kachestvo zhizni naseleniya kak integral'nyi kriterii otsenki effektivnosti deyatel'nosti regional'noi administratsii [Population life quality as an integral criterion for assessing efficiency of activities performed by regional administration]. Nauchnyi zhurnal Kubanskogo gosudarstvennogo agrarnogo universiteta, 2004, vol. 4, no. 2, pp. 171-185 (in Russian).

17. Tatarkin A.I., Kuklin A.A., Vasil'eva E.V., Nikulina N.L. Kachestvo zhizni kak sistemnaya dominanta povysheniya ekonomicheskoi bezopasnosti regiona [Quality of life as the main factor in increasing the economic security of the region]. Vestnik Tyumenskogo gosudarstvennogo universiteta, 2012, no. 11, pp. 38-49 (in Russian).

18. Akhremenko A.S., Evtushenko S.A. Kachestvo zhizni regionov Rossii: politologicheskii aspekt, metodologiya i metodika izmereniya [Quality of life in Russian regions: politological aspect, method and methodology of measurement]. Vestnik Moskovskogo universiteta. Seriya 12: Politicheskie nauki, 2010, no. 1 , pp. $67-83$ (in Russian).

19. Vereshchagin A.I., Fokin M.V., Kalinovskaya M.V. Formirovanie federal'nogo informatsionnogo fonda sotsial'no-gigienicheskogo monitoringa [Forming of federal infor mation fund of socialhygienic monitoring]. Zdorov'e naseleniya i sreda obitaniya, 2006, vol. 163, no. 10, pp. 11-15 (in Russian). 
20. Onishhenko G.G., Zaitseva N.V., May I.V. [et al.]. Health risk analysis in the strategy of state social and economical development. In: G.G. Onishhenko, N.V. Zaitseva eds. Perm', Publishing house of the Perm National Research Polytechnic University, 2014, 738 p. (in Russian).

21. Korotenko G., Shevchenko K. Perspektivy primeneniya ontologicheskikh modelei dlya otsenki znachimosti pokazatelei i indikatorov, primenyaemykh $\mathrm{v}$ sotsial'no-gigienicheskom monitoringe [Prospects of ontological models application in assessing significance of parameters and indicators in socialhygienic monitoring]. Sovremennyi nauchnyi vestnik, 2013, vol. 5, no. 2, pp. 84-90 (in Russian).

22. Barg A.O., Nesevrya N.A. Sotsial'nye faktory riska zdorov'yu: teoretiko-metodologicheskie problemy analiza [Social health risk factors: theoretical and methodological issues in analysis]. Vestnik Permskogo universiteta. Filosofiya. Psikhologiya. Sotsiologiya, 2010, vol. 1, no. 1, pp. 99-108 (in Russian).

23. Lebedeva-Nesevrya N.A., Barg A.O., Solov'ev S.S. Zdorov'e v sub"ektivnykh otsenkakh rabotayushchego naseleniya Rossii [Self-Rated Health of the Working Population in Russia]. Izvestiya Ural'skogo federal'nogo universiteta. Seriya 3: Obshchestvennye nauki, 2017, vol. 12, no. 3 (167), pp. 108-115 (in Russian).

24. Popova A.Yu., Gurvich V.B., Kuz'min S.V., Orlov M.S., Yarushin S.V., Mishina A.L. Nauchnaya kontseptsiya razvitiya normativno-metodicheskoi osnovy obespecheniya sanitarnoepidemiologicheskogo blagopoluchiya naseleniya [The paradigm of the development of the regulatory and methodological framework aimed to maintain sanitary and epidemiological welfare of the population]. Gigiena i sanitariya, 2017, vol. 96, no. 12, pp. 1226-1230 (in Russian).

Popova A.Yu., Zaitseva N.V., May I.V. On implementation of population life qulity assessment into social-hygienic monitoring system. Health Risk Analysis, 2018, no. 3, pp. 4-12. DOI: 10.21668/health.risk/2018.3.01.eng

Received: 20.08 .2018

Accepted: 24.09 .2018

Published: 30.09.2018 